\title{
Platelet-rich fibrin can accelerate the healing of common bile duct anastomosis in a rat
}

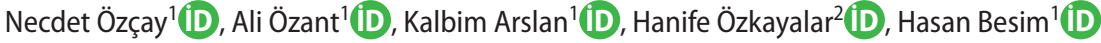 \\ 1 Department of General Surgery, Faculty of Medicine Near East University, Nicosia, Cyprus \\ ${ }^{2}$ Department of Medical Pathology, Faculty of Medicine Near East University, Nicosia, Cyprus
}

\begin{abstract}
Objective: This study aimed to evaluate the effect of platelet-rich fibrin (PRF) concentrate on the bile duct anastomosis healing process in rats.

Material and Methods: Thirty male Sprague Dawley (SD) rats were used for the study. The animals were allocated into three groups: Group I Control Group ( $n=10)$ : Anastomosis to the common bile duct (CBD) with a stent. Group II PRF Group ( $n=10)$ : Anastomosis to the CBD with a stent and covered with PRF. Group III Sham Group ( $n=10)$ : Preparation of the common bile duct, no anastomosis. The animals were followed up for 1 month, then sacrificed. Study parameters were adhesions around the anastomosis, thickness of the bridging bile duct tissue over the stent, and histopathologic examination of the bridging bile duct tissue.
\end{abstract}

Results: CBD anastomosis using a stent caused severe adhesion around the anastomosis, bridging bile duct tissues were weak and histopathologically, healing was incomplete in most of the control animals. However, PRF application significantly reduced the adhesions, increased the quality of the bridging bile duct tissues, and caused complete healing histologically.

Conclusion: PRF is an autologous, easily prepared membrane. The present study findings show that PRF prevents local complications and increases the healing capacity of the bile duct after CBD anastomosis. Therefore, it might be a new treatment option for preventing complications following common bile duct anastomosis in liver transplantation patients.

Keywords: Platelet-rich fibrin, biliary complications, biliary reconstruction, liver transplantation

Cite this article as: Özçay N, Özant A, Arslan K, Özkayalar $\mathrm{H}$, Besim H. Platelet-rich fibrin can accelerate the healing of common bile duct anastomosis in a rat. Turk J Surg 2020; 36 (3): $256-263$

\section{Corresponding Author}

Necdet Özçay

E-mail: necdetozcay@gmail.com

Received: 30.12 .2019

Accepted: 24.06 .2020

Available Online Date: 28.09 .2020

(- Copyright 2020 by Turkish Surgical Society Available online at www.turkjsurg.com

DOI: $10.47717 /$ turkjsurg.2020.4564

\section{INTRODUCTION}

The bile duct and the vascular endothelium are vulnerable to the damaging effects of ischemic, immunologic, and preservation injuries. The regenerative capacity of the biliary tract is also poor and is often compromised further due to ischemic injury (1). Therefore, independent from surgical techniques, biliary complications following hepatobiliary operations and liver transplantation are common and remain a major source of morbidity. Biliary leaks and strictures are the most common complications after liver transplantation, with an incidence of 5\%-32\% (2). The effective management of biliary complications is difficult and always requires additional medical or surgical treatments. Unfortunately, even with advanced interventional or surgical treatments, treatment results are not satisfactory (3).

Platelet-rich fibrin (PRF) is a second-generation platelet concentrate which was first developed by Choukroun et al. (4-5). PRF is a fibrin matrix in which platelets are trapped massively and may be released after a certain time and could serve as an autologous membrane. Fibrin and platelets play crucial roles during the gastrointestinal wound healing process. The formation of fibrin seal on the outer part of the bowel is essential for the early integrity of the anastomosis (6). The fibrin matrix covers the injured tissue and affects the metabolism of inflammatory cells. Fibrin also plays a role as the natural guide of angiogenesis (5). Platelets are anucleate cytoplasmic fragments and contain many granules in which a large amount of growth factors as well as inflammatory and healing cytokines exist. Platelet growth factors are a well-known source of healing, and they also have synergetic effects on healing processes (7). PRF has some advantages over other platelets concentrates, such as easy and quick preparation without any complex manipulations or additives, and prolonged action. These technical advantages and unique structures of PRF have led to the hypothesis that using PRF could accelerate the healing of common bile duct anastomosis. 
The authors believe that the prevention of biliary tract complications is more important than treatment. Promoting the healing process and increasing the regenerative capacity of the biliary system might play an important role in preventing biliary complications following hepatobiliary operations and liver transplantation. PRF has been used to accelerate the healing of skin autografts, oral and maxillofacial tissue and hand wounds with encouraging results for many years (8-12). In this study, it was aimed to investigate the effects of platelet-rich fibrin on the bile duct healing process in rats.

\section{MATERIAL and METHODS}

\section{Animals}

This study was approved by Başkent University Ethical Committee for Experimental Research on Animals (project no: DA16/08). Thirty male outbred Sprague Dawley (SD) rats weighing 250-300 grams were purchased from the experimental animals breeding center at Başkent University in Ankara, Turkey. The animals were housed in the Başkent University Experimental Research Center (Ankara, Turkey) in accordance with the guidelines established by the Turkish Government. Food and water were not restricted from the animals. The rats were anesthetized with an intraperitoneal injection of ketamine $(50 \mathrm{mg} / \mathrm{kg})$ and xylazine $(10 \mathrm{mg} /$ $\mathrm{kg}$ ). The abdomen was cleansed with povidone iodine, and laparotomy was performed via a midline incision. The study groups were designed as follows:

Group I ( $n=10)$ : Anastomosis with stent (Control); Laparotomy, transection of the common bile duct, end-to-end anastomosis with silicon stent, followed-up 1 month, sacrificed.

Group II ( $n=10)$ : Anastomosis with stent and PRF; Laparotomy, transection of common bile duct, end-to-end anastomosis with silicon stent, placement of the PRF membrane around the stent, followed-up 1 month, sacrificed.

Group III ( $n=10)$ : Sham group; Laparotomy, preparation of the common bile duct, followed-up 1 month, sacrificed.

\section{Preparation of the PRF}

The PRF was prepared as previously described by Dohan at al. (4). Briefly, one $\mathrm{ml}$ of blood samples was obtained before the surgical procedures from each animal by cardiac puncture, and poured into a glass centrifuge tube without anticoagulant. The tubes were then immediately centrifuged at 3,000 revolutions per minute (rpm) for 10 minutes in a centrifuge machine (Nüve NF 415). Three centrifugation strata were obtained: a fibrin clot (PRF) in the middle of the tube, between the red corpuscles at the bottom and the acellular plasma at the top. The platelets were trapped in large numbers in the fibrin meshes. The upper straw-colored layer was removed and the middle fraction was collected. A resistant autologous fibrin membrane was then obtained by driving out the serum from the clot.

\section{Surgical Model}

An operating microscope (Carl Zeiss OPMI 9-FC, Germany) was used for the surgical model. A laparotomy was performed via a midline incision. The hepatic hilum was dissected to free the common bile duct (CBD). Then, the CBD was transected at the middle. The CBD was reconstructed by duct-to-duct anastomosis with a stent: the stent was inserted into both ends of the bile duct and was secured with a 7/0 Prolene purse-string suture. The distance between the two sutures was $10 \mathrm{~mm}$. This bare stent area was left between the two sutures to observe migration of the bile duct tissue. The PRF membrane covered the stent and the two ends of the PRF were attached to each other with a 7/0 Prolene suture to prevent sliding of the PRF in the treatment group (Figure 1). The hepatic hilar was dissected to free the CBD in the sham group of animals. The animals were followed-up daily for 1 month, then sacrificed.

\section{Study Parameters}

\section{Gross findings at necropsy}

The anastomotic area of the CBD was quantitatively evaluated by an experienced surgeon in a blinded manner during necropsy. Firstly, adhesions around the CBD anastomosis were evaluated. Anastomotic adhesions were graded from 0-to-III, as modified from Nair et al. (13): Grade 0: No adhesion; Grade I (mild adhesion): A single organ, omentum, duodenum or liver, adherent to the anastomosis; Grade II (moderate adhesion): Two organs adherent to the anastomosis; Grade III (severe adhesion): More than two organs adherent to the anastomosis. Secondly, the bridging bile duct tissue over the silicon catheter was qualitatively evaluated and graded as follows: Grade 0 : Catheter completely visible and there is no bridging bile duct tissue; Grade l: Catheter partially visible and there is partial bile duct tissue over the catheter; Grade II: Catheter is not visible,

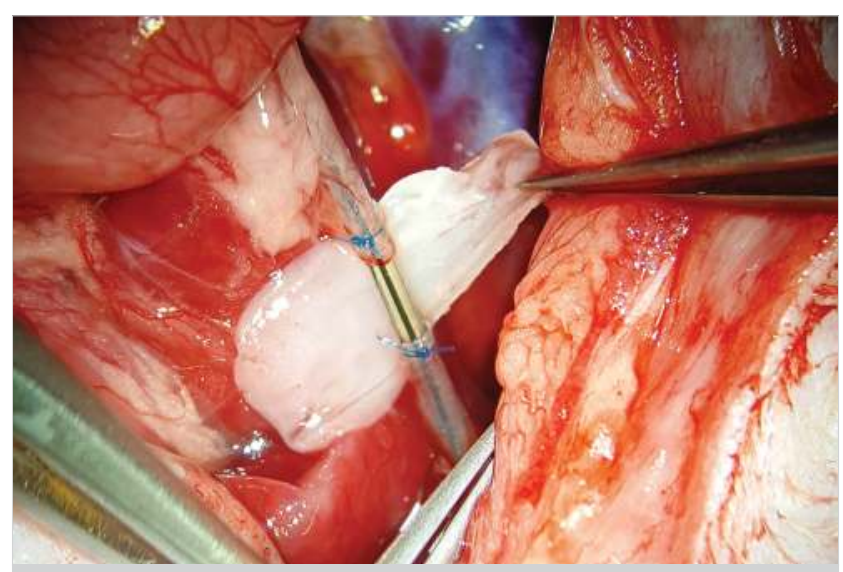

Figure 1. Common bile duct reconstruction by duct-to-duct anastomosis with a stent and application of the PRF membrane. After the PRF membrane covered the stent, the two ends of the PRF were attached to each other with a suture to prevent sliding of. 
complete but thin bridging bile duct tissue exists; Grade III: Catheter is not visible and is covered with thick and strong bile duct bridging tissue. The scores from each of the groups were then totaled and averaged to give a median macroscopic score for each group. Stenosis and/or dehiscence of the anastomosis and CBD dilatation were also recorded during necropsy.

\section{Histopathology}

Full-thickness sections of the CBD anastomosis were obtained at necropsy, fixed in 10\% buffered formalin, embedded in paraffin, cut into 4-to-5 $\mu \mathrm{m}$-thick sections and stained with hematoxylin and eosin. Sections were also stained with Masson's trichrome for the assessment of collagen deposition. A pathologist examined the tissue sections under light microscopy in a double-blinded fashion. Epithelization, cellular infiltration, collagen deposition and neovascularization were graded from $0-2(0=$ absent, $1=$ mild to moderate, 2= marked) as modified from Greenhalgh et al. (14).

\section{Statistical Analysis}

The results are expressed as mean \pm standard deviation (SD). Differences between the groups were analyzed by the Kruskal-Wallis test, followed by the Mann-Whitney $U$ test. Probability values $\mathrm{p}<0.05$ were considered significant. The SPSS 17.0 (SPSS Ver. 17.0, Chicago IL, USA) program was used for analysis.

\section{RESULTS}

Surgery was successful in all of the cases. Cardiac puncture for obtaining blood samples did not cause any problem in animals. Animals were followed up daily for a month according to their general condition, and none of the animals experienced any problems during the study period. All animals reached the end point of the study in a healthy status.

\section{Gross Findings at Necropsy}

There was neither bile leakage nor stent obstruction in the study groups. Only four animals in Group I (control group) had proximal common bile duct dilatation although the lumen of the stents were open.

\section{Intraabdominal Adhesion}

The adhesion scores of the groups are shown in Table 1. Animals in the control group (Group I) showed mild to severe adhesion around the CBD stent; three animals had mild adhesion in which the liver was adherent to anastomotic region. Five animals had moderate adhesion in which the liver and duodenum were adherent, and two animals had severe adhesion in which the liver, duodenum and omentum were adherent to the anastomotic region. Mean adhesion score of the animals in Group I was $1.9 \pm 0.7$. Gross findings during necropsy following 1 month after the operations revealed that all intra-abdominal organs were normal in Group II animals. PRF application dramatically reduced the adhesions around the anastomosis region; seven of the ten animals in this group had no adhesion and three animals had mild adhesion around the CBD stent. The adhesion score of Group II was statistically different to Group I ( $p<0.001)$. The animals in Group III (sham group) largely showed no adhesion or very limited adhesion around the CBD; four animals had no adhesion, four animals had mild adhesion in which the liver was adherent to the $\mathrm{CBD}$, and only two animals in this group had moderate adhesion in which the liver and duodenum adherent to the CBD. The adhesion scores of the PRF group and the sham group were not statistically different $(p=0.422)$.

\section{Bridging Bile Duct Tissue}

Evaluation of the bridging tissue over the plastic stent revealed that only three of the ten animals in Group I developed fully covered tissue. Five animals had very thin bridging tissue around the plastic stent, and in two animals, the plastic stents were visible, which meant that there was very weak healing in these two animals. The bridging bile duct tissue scores of the groups are shown in Table 2.

Table 1. Adhesion scores of the groups (0-to-3)

\begin{tabular}{|c|c|c|c|c|}
\hline Group & $n$ & Mean \pm SD & Median & Min-Max \\
\hline I (Control) & 10 & $1.9 \pm 0.7$ & 2 & $1-3$ \\
\hline II (PRF) & 10 & $0.3 \pm 0.5^{*}$ & 0 & $0-1$ \\
\hline III (Sham) & 10 & $0.6 \pm 0.7$ & 0.5 & $0-2$ \\
\hline
\end{tabular}

Table 2. Bridging bile duct tissue scores of the groups (0-to-3)

\begin{tabular}{|c|c|c|c|c|}
\hline Group & $n$ & Mean \pm SD & Median & Min-Max \\
\hline I (Control) & 10 & $1.9 \pm 0.5$ & 2 & $1-2.5$ \\
\hline II (PRF) & 10 & $2.8 \pm 0.3^{*}$ & 3 & $2-3$ \\
\hline III (Sham) & 10 & N/A & N/A & N/A \\
\hline
\end{tabular}


Table 3. Histologic scores of the groups (0-to-8)

\begin{tabular}{|l|c|c|c|c|}
\hline Group & $\mathbf{n}$ & Mean \pm SD & Median & Min-Max \\
\hline I (Control) & 10 & $4.9 \pm 0.8$ & 5 & $4-6$ \\
\hline II (PRF) & 10 & $6.7 \pm 0.8^{*}$ & 6.5 & $6-8$ \\
\hline III (Sham) & 10 & $4.3 \pm 0.6$ & 4 & $3-5$ \\
\hline *Group II was significantly statistically different when compared with Group I $(\mathrm{p}=0.002)$. & & \\
\hline
\end{tabular}

Most of the animals in Group II developed very thick and dense bridging tissue around the CBD stent; eight of the ten animals had complete and thick coverage of the stent, whereas the other two had complete but relatively thin coverage of the stent. The difference between the PRF and control groups for bridging tissue was statistically different ( $p=0.002)$.

\section{Histopathologic Evaluation}

Histopathologic examination of the bridging tissue showed incomplete healing of the animals in the control group (Group I); the mucosa was a single layer of tall columnar epithelium and the pili and crypt structures were not fully developed (Figure 2a). In the lamina propria, congested vessels and mixed type inflammatory cells infiltrated with polymorphonuclear leukocytes were observed. Cellular infiltration and neovascularization were graded mild to moderate in this group of animals. Most of the control group animals also had weak granulation tissue and collagen deposition. Thin discrete collagen fibers are seen in Figure $2 \mathrm{~b}$ with Masson's trichrome staining. Mean histologic score of the control group was $4.9 \pm 0.8$ (total of 8).

The animals in the PRF group (Group II); however, had almost complete healing one month after the operation. The PRF membranes were not visible and were completely dissolved from the serosal surface of the anastomoses in the PRF treatment group. The mucosa was lined by a single layer of tall columnar epithelium, and the epithelialization, pili and crypt structures were precisely developed. Dense mixed inflammatory cell infiltrated with polymorphonuclear leukocytes, congested and proliferated vessels were observed in the lamina propria (Figure 2c). Similarly, in the macroscopic observations, most of the animals showed very thick granulation tissue in their bridging tissue. Almost all animals in this group had marked epithelization, cellular infiltration, neovascularization and collagen deposition. Multiple thick collagen bundles can be seen in Figure $2 \mathrm{~d}$ with Masson's trichrome staining. The histologic score of the PRF group was significantly higher than the control group $(p=0.002)$.

The sham group of animals had no CBD anastomosis, and therefore there was no healing process in this group. Histopathologic examination of this group showed normal histologic appearance of the CBD. The mean histologic score of the sham group of animals was $4.3 \pm 0.6$. The histopathologic scores of the groups are shown in Table 3.

\section{DISCUSSION}

PRF is a second-generation autologous platelet concentrate with simplified processing without biochemical blood handling. Use of bovine thrombin and anticoagulants is not required during the preparation. It has significant capacity to support cell migrations and healing processes, and therefore, it has been described as a completely usable healing concentrate by Dohan et al. (7). It is well known that platelets play a prominent role in wound healing (1). PRF is a rich source of platelets containing endogenous growth factors, cytokines and several other wound-healing stimulating factors (15-18). Platelets release cytokines and growth factors during clot formation at the wound site. Platelet activation in response to tissue damage results in the secretion of biologically active proteins from the a-granules. These include platelet-derived growth factor (PDGF), transforming growth factor $\beta-1$ (TGF $\beta-1$ ), interleukin (IL)-1, vascular endothelial growth factor (VEGF), platelet-derived angiogenesis factor (PDAF), epidermal growth factor (EGF), insulin-like growth factor (IGF), epithelial cell growth factor (ECGF), osteonectin, osteocalcin, fibrinogen, vitronectin, fibronectin, and thromboplastin (7). These secretory proteins simultaneously support angiogenesis, immunity, and epithelial cover during healing. Fibrin matrix of PRF also plays an important role during the healing process. Fibrin is the natural guide for angiogenesis, and it also stimulates the metabolism of epithelial cells and fibroblasts (5). Thus, with all these mechanisms, PRF accelerates healing, increases the development of microvascularization and also guides epithelial cell migration to the stent surface (19).

The improvement of healing by the placement of autologous PRF concentrate at the site of tissue injury is supported by previous studies. There are studies that provide evidence that the use of PRF has some beneficial effects in certain types of wounds and causes an increase in hard- and soft-tissue wound healing; For example, Visser et al. (20) have used PRF to enhance the healing process in the patellar tendons of dogs and found that PRF increases the amount of tissue reconstruction. Inchingolo et al. (21) have used PRF in sinus lift procedures and demonstrated a significant increase in peri-implant bone density and implant stability.

PRF has been mainly used for many years by dentists for oral and maxillofacial surgery and plastic surgeons for facial plastic procedures and skin autografts with promising results (8,22-24). 

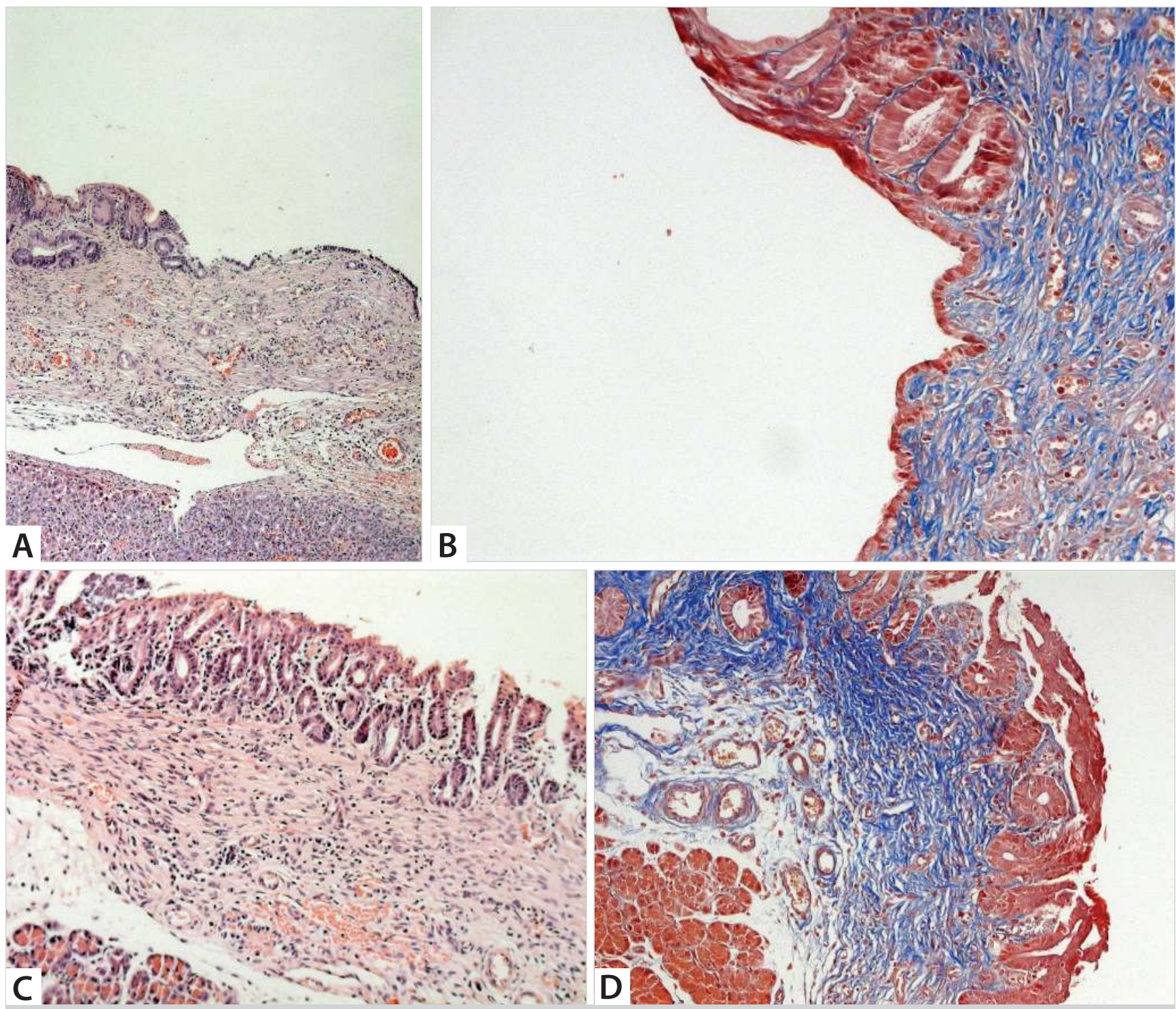

Figure 2. a. The junction of the common bile duct and the bridging tissue in the control group. A single layer of columnar epithelium is seen in the biliary mucosa, while pili and crypt development are not evident at the bridging tissue site (Hematox). $\mathbf{b}$. Thin discrete collagen fibers of a control group animal (Masson's trichrome, X20). c. The bridging tissue histological view of the experimental (PRF) group. A single layer of biliary epithelium with fully developed pili and crypt formation is seen, while the lamina propia has dense mixed inflammatory infiltrate (Hematoxylin) d. Thick collagen bundles of a PRF group animal (Masson's trichrome, X20).

However, there is no clinical data about intra-abdominal usage of PRF in the literature. One of the reasons for that might be due to concerns about its fibrin content, which may cause adhesion when used intra abdominally. However, a recently published experimental study demonstrated that intra-abdominal usage of PRF is very safe and does not cause any adhesion in the abdominal cavity (25). Moreover, PRF reduces the adhesion and accelerates the intestinal anastomosis wound healing. This result supports our observation in this study as one of the main findings in our study was decreased adhesion around the CBD anastomosis site when PRF was applied. There was a significant difference between the PRF and control group adhesion scores in our study. Most of the animals in the PRF group had an almost complete lack of adhesion, whereas most of the control animals had severe adhesion. Manipulation of the CBD, suture materials, and silicon catheter cause adhesion around the anastomosis. However, PRF application efficiently prevents this effect, possibly because it is an autologous and degradable material.

One of the other main findings of the present study was the increased regenerative capacity of the biliary tract when PRF was applied. Macroscopic observations revealed that the application of PRF significantly increased bridging tissue thickening 
over the plastic stent. There was complete and thick bridging tissue coverage around the anastomosis in most of the animals. This observation was supported by histopathological examinations: histologically, these bridging tissues had almost the same structure as the bile duct; dense collagen deposition and bile duct gland proliferation were observed in the anastomosis one month after operation. There were tall, uniform columnar cells in the epithelium with mucosal longitudinal folds. The sub-epithelial regions were also very similar to CBD and had dense, hypocellular connective tissue with few lymphocytes. It is well known that the biliary tissue can migrate along the surface of synthetic materials (26). Our findings indicate that PRF application increases tissue migration and proliferation of the cells. The mechanism of this effect might be mechanical rather than promoting wound healing. However, regardless of the mechanism, PRF has a beneficial effect on the bile duct healing process.

The main advantages of PRF over other platelet concentrates are that it is not necessary to add bovine thrombin or other anti-coagulants, thus it is completely safe, easy to use and requires standard preparation and handling by clinicians. The only disadvantage of PRF might be the amount of material required. It is not suitable for large surfaces, such as the abdominal cavity, since only a small amount of PRF could be obtained from the limited volume blood sample. However, CBD anastomosis or any type of biliary-enteric anastomosis sites are small areas and PRF concentrates are sufficient to cover these areas.

PRF preparation is very simple and does not require anticoagulant or bovine thrombin. Around $5 \mathrm{ml}$ of whole venous blood collects in each of the two sterile vacutainer tubes of $6 \mathrm{ml} \mathrm{ca-}$ pacity without anticoagulant. The tubes should then be placed in a centrifugal machine as quickly as possible. Blood collection and transfer to the centrifuge must be completed within minutes, because without the anticoagulant, the blood sample will begin to coagulate almost immediately on contact with the glass tube. Quick handling is the only way to obtain a clinically usable PRF clot. The tubes centrifugate at 3.000 rpm for 10 minutes, after which it settles into the following layers: the red lower fraction contains red blood cells, the upper straw-colored cellular plasma and the middle fraction contains the fibrin clot. The upper and lower layers are removed and the middle fraction can be collected, which is the PRF. The PRF membrane is then cleaned using physiological saline to remove blood clots and after that, it is ready for use. In this technique, fibrinogen combines with the circulating thrombin due to centrifugation to form fibrin. Thus, the use of anticoagulant and the addition of bovine thrombin to promote conversion of fibrinogen to fibrin is avoided. This preparation could be performed in the operating theatre during the operations and the PRF membrane could be applied immediately after preparation onto the CBD anastomosis sites.

One of the main problems in hepatobiliary surgery and liver transplantation is biliary complications (27-30). Biliary leaks and strictures are still very common and cause major morbidity and mortality after these operations. Refined surgical methods have decreased the bile duct anastomosis complications; however, they are not eradicated. Since the bile duct is a vulnerable organ, it is very sensitive to ischemic injury and also has low regenerative capacity. Therefore, regardless of the surgical technique, the possibility of bile duct anastomosis problems will always exist for surgeons. Accelerating healing and increasing the regenerative capacity of the bile duct might be solutions to prevent these complications. This study evaluated the effect of PRF on the bile duct healing process with some macroscopic and microscopic parameters. According to our findings, it could be said that PRF has some beneficial effects on the bile duct healing process. There is no data available in the literature regarding PRF application on bile duct anastomosis healing process. Therefore, the results of this original study may help surgeons to prevent bile duct complications. However, the mechanism of these effects and biochemical changes such as liver function tests or cytokines levels have not been studied. These represent the main limitations of the present study. Further studies are necessary to answer these questions.

\section{CONCLUSION}

PRF is a safe, autologous and degradable material which contains high amounts of platelets and fibrin. Preparation is very simple and only requires a $10 \mathrm{ml}$ venous blood sample from the patient as well as a centrifuge machine. Preparation of the PRF only takes a few minutes and could easily be done in the theatre during the operation. The present study results indicate that PRF application reduced the adhesion around the anastomosis and increased the healing. Therefore, it could be said that PRF is an alternative solution to prevent complications following common bile duct anastomosis in liver transplantation patients.

Ethics Committee Approval: Ethic committee approval was received for this study from Başkent University Ethical Committee for Experimental Research on Animals (DA 16/08; 15.02.2016/16-09).

Peer-review: Externally peer-reviewed.

Author Contributions: Concept - N.Ö.; Design - N.Ö.; Supervision - N.Ö.; Resource - N.Ö., H.Ö.; Materials - N.Ö., H.Ö.; Data Collection and/or Processing - N.Ö., A.Ö., K.A., H.Ö.; Analysis and Interpretation - N.Ö.; Literature Review K.A., A.Ö.; Writing Manuscript - N.Ö.; Critical Reviews - H.B.;

Conflict of Interest: The authors have no conflicts of interest to declare.

Financial Disclosure: The authors declared that this study has received no financial support. 


\section{REFERENCES}

1. Jagannath S, Kalloo AN. Biliary complication after liver transplantation. Curr Treat Options Gastroenterol 2002; 5: 101-12. [CrossRef]

2. Kochhar G, Parungao JM, Hanounah IA, Parsi MA. Biliary complications following liver transplantation. World J Gastroenterol 2013; 19: 2841-6. [CrossRef]

3. Coelho JCU, Leite LO, Molena A, Freitas ACT, Matias JEF. Biliary complications after liver transplantation. Arq Bras Cir Dig 2017; 30: 127-31. [CrossRef]

4. Dohan DM, Choukroun J, Diss A, Dohan SL, Dohan AJ, Mouhyi J, et al. Platelet-rich fibrin (PRF): A second-generation platelet concentrate, Part l: Technological concepts and evolution. Oral Surg Oral Med Oral Pathol Oral Radiol Endod 2006; 101: e37-44. [CrossRef]

5. Prakash S, Thakur A. Platelet concentrates: Past present and future. J Maxillofac Oral Surg 2011; 10: 45-9. [CrossRef]

6. Thornton FJ, Barbul A. Healing in the gastrointestinal tract. Surg Clin North Am 1997; 77: 549-73. [CrossRef]

7. Dohan DM, Choukroun J, Diss A, Dohan SL, Dohan AJ, Mouhyi J, et al. Platelet-rich fibrin (PRF): A second-generation platelet concentrate Part II: Platelet-related biologic features. Oral Surg Oral Med Oral Pathol Oral Radiol Endod 2006; 101:e45-50. [CrossRef]

8. Danielsen P, Jorgenson B, Karlsmark T, Jorgensen LN, Agren MS. Effect of topical autologus platelet-rich fibrin versus no intervention on epithelialisation of donor sites and meshed split-thickness skin autografts: a randomized clinical trial. Plast Reconstr Surg. 2008; 122: 1431-40. [CrossRef]

9. Saluja H, Dehane V, Mahindra U. Platelet-rich-fibrin: a second generation platelet concentrate and a new friend of oral and maxillofacial surgeons. Ann Maxillofac Surg 2011; 1: 53-7. [CrossRef]

10. Desai CB, Mahindra UR, Kini YK, Bakshi MK. Use of platelet-rich-fibrin over skin wounds: modified secondary intention healing. J Cutan Aesthet Surg 2013; 6: 35-7. [CrossRef]

11. Naik B, Karunakar P, Jayadev M, Marshal VR: Role of platelet rich fibrin in wound healing: a critical review. J Conserv Dent 2013; 16: 284-93. [CrossRef]

12. Sclafani AP. Safety, efficacy, and utility of platelet-rich fibrin matrix in facial plastic surgery. Arch Facial Plast Surg 2011; 13: 247-51. [CrossRef]

13. Nair SK, Bhat IK, Aurora AL. Role of proteolytic enzyme in the prevention of postoperative intraperitoneal adhesions. Arch Surg 1974; 108: 849-53. [CrossRef]

14. Greenhalg DG, Sprugel KH, Murray MJ, Ross R. PDGF and FGF stimulates healing in the genetically diabetic mouse. Am J Pathol 1990; 136: 1235-46. [CrossRef]

15. Eppley BL, Pietrzak WS, Blanton M. Platelet-rich plasma: a review of biology and applications in plastic surgery. Plast Reconstr Surg 2006; 118: 147e-59e. [CrossRef]
16. Anitua E, Andia I, Ardanza B, Nurden P, Nurden AT. Autologous platelets as a source of proteins for healing and tissue regeneration. Thromb Haemost 2004; 91: 4-15. [CrossRef]

17. Barrientos S, Stojadinovic O, Golinko MS, Brem H, Tomic-Canic M. Growth factors and cytokines in wound healing. Wound Repair Regen 2008; 16: 585-601. [CrossRef]

18. Roukis TS, Zgonis T, Tiernan B. Autologous platelet-rich plasma for wound and osseous healing: a review of the literature and commercially available products. Adv Ther 2006; 23:218 -37. [CrossRef]

19. Choukroun J, Diss A, Simonpieri A, Girard MO, Schoeffler C, Dohan SL, et al. Platelet-rich fibrin (PRF): A second-generation platelet concentrate. Part IV: Clinical effects on tissue healing. Oral Surg Oral Med Oral Pathol Oral Radiol Endod 2006; 101: e56-60. [CrossRef]

20. Visser LC, Arnoczky SP, Caballero O, Gardner KL. Evaluation of the use of an autologous platelet-rich fibrin membrane to enhance tendon healing in dogs. Am J of Vet Res 2011; 72:699-705. [CrossRef]

21. Inchingolo F, Tatullo M, Marrelli M, Inchingolo AM, Scacco S, InchingoIo AD, et al. Trial with Platelet-Rich Fibrin and Bio-Oss used as grafting materials in the treatment of the severe maxillar bone atrophy: clinical and radiological evaluations. Eur Rev Med Pharmacol Sci 2010; 14: 1075-84. [CrossRef]

22. Hom DB, Linzie BM, Huang TC. The healing effects of autologous platelet gel on acute human skin wounds. Arch Facial Plast Surg 2007; 9: 174-83. [CrossRef]

23. Singh A, Kohli M, Gupta N. Platelet-rich fibrin: a novel approach for osseous regeneration. J Maxillofac Oral Surg. 2012; 11:430-34. [CrossRef]

24. Ruga E, Gallesio C, Boffano P. Platelet-rich fibrin and piezoelectric surgery: a safe technique for the prevention of periodontal complications in third molar surgery. J Craniofac Surg 2011;22: 1951-55. [CrossRef]

25. Ozcay N, Ozdemir H, Besim H. Role of platelet-rich fibrin on intestinal anastomosis wound healing in a rat. Biomed Mater. 2018; 13:045006. [CrossRef]

26. Rauws EAJ, Gouma DJ. Endoscopic and surgical management of bile duct injury after laparoscopic cholecystectomy. Best Pract Res Clin Gastroenterol 2004; 18: 829-46. [CrossRef]

27. Karanikas M, Bozali F, Vamvakerou V, Markou M, Chasan ZT, Efraimidou E, et al. Biliary tract injuries after lap cholecystectomy-types, surgical intervention and timing. Ann Trans/ Med 2016; 4:163. [CrossRef]

28. Suo T, Chen L, Liu H, Ni X, Shen S, Wang Y, et al. Management for a complicated biliary stricture after iatrogenic bile duct injury. J Vis Surg 2017; 17: 3-33. [CrossRef]

29. Lauterio A, De Carlis R, Di Sandro S, Ferla F, Buscemi V, De Carlis L. Liver transplantation in the treatment of severe iatrogenic liver injuries. World J Hepatol 2017; 9: 1022-29. [CrossRef]

30. Vachhani PG, Copelan A, Remer EM, Kapoor B. latrogenic hepatopancreaticobiliary injuries: a review. Semin Intervent Radiol 2015; 32: 182-94. [CrossRef] 


\section{ORIJINAL ÇALIŞMA-ÖZET}

\section{Trombositten zengin fibrin sıçanlarda safra yolu anastomoz yara iyileşmesini hızlandırabilir}

Necdet Özçay ${ }^{1}$, Ali Özant ${ }^{1}$, Kalbim Arslan ${ }^{1}$, Hanife Özkayalar ${ }^{2}$, Hasan Besim ${ }^{1}$

${ }^{1}$ Yakın Doğu Üniversitesi Tıp Fakültesi, Genel Cerrahi Anabilim Dalı, Lefkoşa, Kıbrıs

${ }^{2}$ Yakın Doğu Üniversitesi Tıp Fakültesi, Tıbbi Patoloji Anabilim Dalı, Lefkoşa, Kıbrıs

\section{ÖZET}

Giriş ve Amaç: Trombositten zengin fibrin (PRF) konsantresinin sıçanlarda ana safra yolu anastomoz yara iyileşmesi üzerine etkisinin araştırılması amaçlanmıştır.

Gereç ve Yöntem: Çalışma için otuz adet Spraque-Dawley cinsi erkek sıçan kullanıldı. Çalışma grupları şu şekilde dizayn edildi: Grup I, Kontrol grup ( $n=10)$ : Plastik stent üzerinden ana safra yolu (ASY)' na anastomoz. Grup II, PRF Grubu ( $n=10)$ : Plastik stent üzerinde ASY'ye anastomoz ve PRF ile anastomoz bölgesinin kaplanması. Grup III, Sham grubu $(n=10)$ : ASY orta kısmının preparasyonu, anastomoz yapılmadı. İşlem sonrası hayvanlar 1 ay takip edildi ve çalışma sonlandıııldı. Çalışma parametreleri; anastomoz bölgesindeki yapışıkıklar, stent üzerindeki köprü dokunun kalınlığı ve bu dokunun histopatolojik incelenmesi ile yara iyileşmesinin durumu değerlendirildi.

Bulgular: Kontrol grubundaki hayvanların çoğunluğunda anastomoz bölgesinde yoğun yapışıklık saptandı. Ayrıca bu hayvanların stent üzerindeki köprü dokuları ince görünümlü idi ve histolojik olarak da bu bölgede tam yara iyileşmesi olmadığı görüldü. Buna karşın PRF uygulanan hayvanların çoğunluğunda anastomoz bölgesinde hiç yapışıklık yoktu, stent üzeri oldukça kalın bir köprü doku ile kaplıydı ve bu bölgenin histolojik incelenmesinde tam yara iyileşmesi olduğu görüldü.

Sonuç: Bu çalışmamızda PRF uygulamasının ana safra yolu anastomozlarında yapışıkık gibi lokal komplikasyonları önlediği ve aynı zamanda yara iyileşmesini de artırdığı saptandı. Bu nedenle PRF uygulaması, ana safra yolu cerrahi işlemleri gerektiren karaciğer nakli veya diğer bu bölge ameliyatlarından sonra görülen komplikasyonların önlenmesi amacıyla kullanılabilir.

Anahtar Kelimeler: Trombositten zengin fibrin, karaciğer transplantasyonu, yara iyileşmesi, safra yolu yaralanması

Doi: $10.47717 /$ turkjsurg.2020.4564 